\title{
Cross Border Co-Operation through Tourism Promotion \& Cultural Exchange: A Case Study along Nepal and China (T.A.R.) OBOR-Prospective
}

\author{
Lochan Kumar Batala1, Kalpana Regmi², Giriraj Sharma1 \\ ${ }^{1}$ School of Public Affairs, University of Science and Technology of China, Hefei, China \\ ${ }^{2}$ School of Economics and Management, Anhui Agriculture University, Hefei, China \\ Email: 2502557934@qq.com, lochan@mail.ustc.edu.cn
}

How to cite this paper: Batala, L.K., Regmi, K. and Sharma, G. (2017) Cross Border Co-Operation through Tourism Promotion \& Cultural Exchange: A Case Study along Nepal and China (T.A.R.) OBOR-Prospective. Open Journal of Business and Management, 5, 105-118.

http://dx.doi.org/10.4236/ojbm.2017.51010

Received: October 18, 2016

Accepted: December 25, 2016

Published: December 28, 2016

Copyright (c) 2017 by authors and Scientific Research Publishing Inc. This work is licensed under the Creative Commons Attribution International License (CC BY 4.0).

http://creativecommons.org/licenses/by/4.0/ (c) (i) Open Access

\begin{abstract}
Tourism is one of the largest and promising industries in the world. Tourism industry obviously could be one of the milestones for underdeveloped countries' sluggish economy to uplift. This paper advocates and gives the bird eye of view on cross border tourism co-operation and marketing along Nepal and Tibetan autonomous region (China); in addition it describes the ideas of co-operation in various streams of China-Nepal development prospects. Tourism is the potential prime industry in Tibetan autonomous region and Nepal as well. Comparing the facts Tibetan tourism industry is booming, and on the other hand Nepal's tourism is fragile and immature. In this exploratory review paper, we accepted the famous marking model propounded by Igor Ansoff, 1979. Based on Igor model we found numerous potential marketing strategies for development and co-operation in tourism industries along Nepal and TAR. Recently "the one belt one road" is a very hot proposal prolonged by Chinese president "Xi Jinping". This paper also gives a blueprint for the immediate bilateral co-operation along belt and road strategy in Nepal and Tibetan autonomous region frontier.
\end{abstract}

\section{Keywords}

Tourism Co-Operation, Tourism Marketing, One Belt One Road Strategy

\section{Introduction}

Tourism is a multidimensional crucial development parameter of the world economy. Travel \& Tourism's impact on the economic and social development of a country can be enormous: opening it up for business, trade and capital investment, creating jobs and entrepreneurialism for the workforce and protecting heritage and cultural values. “Travel \& Tourism generated US\$7.6 trillion (10\% of global GDP) and 277 million jobs 
( 1 in 11 jobs) for the global economy in 2014" [1]. Tourism has played a vital role in destination development. "Developing a network approach of countries in terms of economy generation has also created the opportunities for tourism participating industries to set the standard at the international level" [2]. Tourism industry can be ample for developing world to uplift economic and social empowerments. According to [3], tourism could be the milestone to reduce extreme poverty in south Asian countries. Hereafter tourism can stimulate development in terms of income, employment, foreign exchange earnings and taxation, as well as exchange cultural understanding and cohesion around the world.

\section{Significance of the Study}

As we know tourism industry remains as the key contributor in the world economy. The trend of international tourist's arrivals grew by 4.4\% in 2015; it accounted for 1184 million in 2015. It shows 50+ million in 2015 as compared to $2014^{1}$. Emphasizing those current positive trends of world tourism, our research focuses on China. It is a great pore to the world market that Chinese outbound tourism contributes a leading role. According to the UNWTO annual report, among the world's top source markets, China has double digit growth in expenditure every year since 2004

(http://media.unwto.org). Chinese tourists had taken the first place in world outbound tourism by 2012 surpassing USA and Germany outbound travelers. In 2014, it ac 107.27 million overseas trips were taken by Chinese tourists ${ }^{2}$. Being a neighboring country of China, Nepal certainly needs to take advantage from Chinese outbound tourism market. There is significant increment of Chinese tourists in Nepal in recent years; however the number is still lagging behind as opposed to potentialities.

TAR accounts for 30 percentages of regional GDP contributed by tourism industries. Nepal has $1425 \mathrm{~km}$ long border with the TAR region and has much similar tourism and cultural product. According to the local tourism authority, 95 percents tourists came from inland China. Hence there is a vast silver line for Nepalese tourism industry if government, private sectors and business personals are able to promote the Nepalese tourism and cultural products. Since Nepal decided to be a part of the One Belt One Road Initiatives as well as the founding member of AIIB, the opportunity for Nepal seems risen to grab and materialize through this initiative. China has already nominated Nepal as a member (http://gansu.gansudaily.com.cn/system/2014/06/15/015051768.shtml) of Silk Road tourism cities. Nepal needs to do more cooperation with China's TAR region for tourism marketing and develop infrastructural interconnectivity. The core idea of conducting this research work is about how Nepal can cooperate and be a part of One Road One Belt initiative; how to promote and sell Nepalese touristic and cultural product in China; and to find out the better possible (solution) model of co-operation between Himalayan frontier trade and tourism.

\section{Background of the Study}

\subsection{Belt and Road Strategy}

In 2013, Chinese president Xi Jinping has recalled and has taken the initiatives of pro${ }^{1}$ http://media.unwto.org/press-release.

${ }^{2}$ http://www.stats.gov.cn. 
moting the "The Belt and Road" strategy. The "One Belt" also refers to the Silk Road economic belt, and "Road" refers to the $21^{\text {st }}$ century maritime road knots, (abbreviated OBOR). The belt and road strategy has become the important guideline of China's domestic economic development driver as well as China's foreign policy strategy ${ }^{3}$. Silk Road economic belt is one of the ultimate visionary development and jointly co-operation strategy of China along its neighbor and ancient silk route corridors countries. "The new economic connections recall notions of the ancient Silk Road, in that an increase in trade and mobility will bring peripheral regions (Bangladesh, Bhutan, Myanmar, Nepal, and northeast Indian states etc.) into greatest co-operation with China" [4]. The building of the Silk Road economic belt is an exciting prospect that may bring immense economic benefits through competitive geo-advantage along countries. Nepal is located in China's one of the important geo-politics frontier; it plays an important role in China's south Asia policy as it forms the crucial entry point for China in to sub-continent. As always China's strategic interest in Nepal is also heightened because of it being amid-gateway in to restive Tibetan region. The issue of Tibet is an important variable which has strongly influenced Sino Nepal relations. Apart from the historical linkages, the present geo political scenario and the domestic problems that China is facing in Tibet makes Nepal strategically important for Beijing [5]. Hereafter historically interlineate terrain of Nepal and T.A.R. frontier need to look further for mutual co-operation and exchange in term of 21 st century developing prospect to fruitful coexist relation lift further solidified win-win model, in term of various aspect of "Cross border co-operation through Tourism Promotion \& Cultural exchange”. After the two massive devastated earthquake ${ }^{4}$ on April $25^{\text {th }}$ Gorkha epicenter and may $5^{\text {th }}$ Singhupalchok epicenter ${ }^{5}$ 2015, Nepalese tourism industry heavily suffering, many historic tourist monuments became debris numbers of tourists trekking route went fragile and being blocked, after the nearly one year government re-constructers mostly destination are rejuvenating, Therefore Nepal need to focus rebound all potential tourist source markets to cover and develop more advance tourism industry in Nepal. In this paper we want to explore the possible core idea of mutually benefits co-operation between Nepal and China, meanwhile we want try to interlink this core concept to emphasis Chinese initiatives one belt one road economic co-operation in-term of tourism development and cultural exchange.

\subsection{Tourism History in Nepal}

Tourists have arrived in some form or the other from time immemorial in Nepal. According to [6] \& [7] the legend Manjushree came to Nepal and made Kathmandu as a live in place by cutting out the gorge at Chovar Kathmandu to follow the drain. There is lack of vivid evidence Majushree ${ }^{6}$ reportedly assumed as Tibetan either Indian touristy came to ancient Nepal as a first tourist. During those days foreigners came to Nepal were Chinese, Tibetan \& Indians, and they used to visit Nepal especially with religious and commercial motives. Nepal was a famous pilgrimage for both the Chinese and In-

${ }^{3}$ https://en.wikipedia.org/wiki/One_Belt,_One_Road.

${ }^{4}$ http://www.bbc.com/news/world-asia-32461019.

${ }^{5}$ http://edition.cnn.com/2015/05/12/asia/nepal-earthquake/index.html.

${ }^{6}$ https://en.wikipedia.org/wiki/Manjushri. 
dians. The Chinese and Tibetan religious groups used to visit Lumbini, the birth place of Lord Buddha, while the Indian religious people used to visit holy places like PashupatiNath, BarahaKshetra, Muktinath, Gosainkunda, etc. Similarly, Nepalese traders used to go to Lhasa for business purposes and the Tibetan traders also found to have come to Nepal in connection with their business activities. Thus religious and trading sectors are found to have contributed significantly to the development of tourism in Nepal. According to the [8], entrance to Nepal was still tightly restricted during early period in the 1950s, with the primary foreign visitors being development officials and scientists. Tourist visas were not granted by the government, and plans for tourist development were nonexistent. "In 1995 one of the Russian citizen being friend of royal family's was able to convince the King to issue tourist visas and to allow the opening of the first hotel for foreign visitors was owned by Lissanevitch himself" [9]. After being operating the Kathmandu airport in 1949 AD concrete the foundation of tourism industry in Nepal, the modern history of tourism in Nepal notably exposed after the advent of democracy in Nepal onward 1950 AD. "After the successfully ascending Mt Everest (highest peak in the world) the very first time by Nepali citizen Tenjing Norbe Sherpa and New Zealander sir Edmund Hillary in 29th May 1953, did much published Nepal as a magnifies Tourism Destination" [8]. It believed the systematic group tourism has taken place in Nepal late 1957 AD [10]. Tourism recognized the largest industry in term of generate foreign exchange in Nepalese economy, although the industry under the actability of its abundant touristic resource. Hereafter every government gives highly strategic importance to encourage and promote tourism industry in Nepal. Tourism history of Nepal is very short; Tourism Development Board was established in 1957 AD. In 1959 AD government established the Tourism Department and it recorded tourism activities. Tourism Master Plan was made in 1972 and the country now began to function in periodic system of implementation of tourism plans and policies. When Ministry of Tourism was set up in 1977 AD then the tourism activities, policies and plans began to be more effective and the country gradually approached to introduce Nepal to many potential places in the world from which travelers could make Nepal a visit destination. Nepal Tourism Board has been actively playing various promotional roles for the tourism development in the country [10].

\subsection{Tourism in Tibetan Autonomous Region}

Tibet is averaging more than 4000 meters above sea level, is well known as the "Roof of the World". Mount Everest ( $8848 \mathrm{~m}$ above sea level), which is located on the border with Nepal, is the highest mountain on earth [11]. Tibet has 1300 years' precious history; the plateau covering with 1.2 million square $\mathrm{km}$ territories is situated on the Qinghai-Tibet Plateau in the south-western border area of China. It enjoys unique plateau environment. Averaging more than 4000 meters in elevation, it is always regarded as the highest region in the world and is known as "the roof of the world". Tibet abuts on Xinjiang, Qinghai, Sichuan, and Yunnan province. It has $3842 \mathrm{~km}$ borders with China's neighboring countries of Myanmar, India, Bhutan and Nepal as well as Kashmir in the south and west. Tourism industry is playing magnificent role in TAR economy significant tourism industry taken place in the tertiary after the Chinese reform and opening 
up, the tourism industry dramatically taken place as long and after the Qinghai-Tibet railways inaugurated in 2006 afterward. "Tibet record numbers of tourist in 2015, nearly 20 million. Tourists visited the TAR and generates 4.26 billion US dollars revenues in local economy"7 tourism industry is one of the focusing centered idea over TAR by TAR government as well as Central Government. According to the China daily report the capital city of TAR Lhasa will generate 30 billion RMB by 2020 , estimated 150,000 new job ${ }^{8}$. The tremendous support for boosting tourism industry in Tibet enhance after the world high land Qinghai-Lhasa train operated in 2006. Qinghai-Lasha High land rail network create bundles of opportunity for TAR tourism. According the [12] empirical research study "The Qinghai-Tibet Railway identified Important destination choice factors for Tibetan tourism, The importance of the railway to tourists' destination choice of Tibet and in their overall travel experience of Tibet is confirmed". further talking about the Chinese president Xi's brilliant mind stroke the 21st century belt and road economic initiatives it more centric to develop China's less-developed western region which is TAR, Yunnan, Qinghai, and some other western provinces. The trend of Chinese current elite more focuses on those region developments to promote tourism promotion and destination management by putting huge infrastructure and creating connectivity development. The $13^{\text {th }}$ five year plan drafted second railway road from Chengdu-Lhasa in order to promote regional interconnectivity and tourism resources $^{9}$ also considering to loosen the travel permit for Aliens in TAR to promote and make the Tibetan plateau is a world leading travel destination ${ }^{10}$.

\subsection{Historical Relationship Nepal-TAR (China)}

Relation begun between Nepal and Tibet (China) since medieval. The princess of Lichhivi regime (600CE) named "Bhirkuti" also named "Bal-mo-bza' Khri-btsun, BhelsaTritsun" in Tibetan Language, got married with Tibetan Emperor "Songstsan Gammbo" (605-650 CE) and believed that she contributes a lot to explore Buddhism and Nepali Art and Culture over Tibet ${ }^{11}$. Historical records shows that friendly exchange of Nepal and China dated back to as early the mid-7th century at that time China and Nepal already started exchanging emissaries. Fahien Chinese eminent monk in the Jin dynasty and Huen Tsang, another famous eminent monk in the Tang dynasty visited "Lumbini" the birth place of Lord Buddha ${ }^{12}$. While we talk about the history of Nepal-China relationship we can't forget the legend "Araniko" in Chinese "ah nige" $(1245-1306)^{13}$, which had been contributed to ancient Nepali Art (pagoda) to explore in China. As toady Nepal only the viable neighbor country attached with TAR. The relationship between Nepal and TAR is limited on not only culture and religious aspects but also various streams. Nepal accounts for $80 \%$ trade transition with TAR. Recent year the connection between Nepal and TAR not only limited on sky pass also road-

${ }^{7}$ http://news.xinhuanet.com/english/2016-01/27/c_135050351.htm.

${ }^{8}$ http://www.Chinadaily.com.cn/China/2016-01/11/content_23016505.htm.

${ }^{9} \mathrm{http}: / / \mathrm{www}$.Chinadaily.com.cn/m/chengdu/wenjiang.

${ }^{10} \mathrm{http}: / /$ www.Chinadaily.com.cn/China/.

${ }^{11}$ https://en.wikipedia.org/wiki/Bhrikuti.

${ }^{12}$ http://np.China-embassy.org/eng/ChinaNepal.

${ }^{13}$ https://en.wikipedia.org/wiki/Araniko. 
ways connection from Kathmandu to Lasha. The central government of PRC has possesses significant technological capability to develop high altitude connectivity related infrastructure targeting to boost Nepal and TAR connectivity (https://jamestown.org/program/Chinas-strategic-advantage-in-nepal/) sever mega infrastructure are undergoing towards Nepal frontier such as airways connectivity, railways connectivity, communication infrastructures so on.

\section{Cross Border Tourism Co-Operation}

There is no absolute definition on cross-border tourism, [13] described that a day trip whether for leisure, business, visiting friends and relatives or grocery shopping, is a form of tourism if it crosses an international border. Likewise the effort contributed by the international co-operation in tourism up to the present time in developing countries is appreciable [14]. "Partnerships have become a popular tourism management strategy for leveraging scare resources in the era of fiscal constraint, special facilities skills are needed to sustain and nurture tourism co-operation" [15]. According to the [16] and [17], collaboration is the presupposed broad and open communication and adaptability to be a key components in addressing joint issues and maintaining fruitful and satisfactory cooperation and interaction. Integration in to the border area has become an economic and technical precondition to survival, with integration process requiring networked spatial arrangements; this concept exceeds restrictions imposed by the national economy framework. They also highlighted boundaries have most often been viewed through history as visible barriers to interconnectivity among people, today number of successful examples of cross-border tourism cooperation in wealthy countries is growing. The world is full of examples of neighboring regions of different countries sharing priceless natural or cultural resources that have potential for joint tourism development. In some of these regions, the principles of sustainable development can be implemented more efficiently through cross-border cooperation. However, all of these cases require the support and approval of the government. In addition, a special tourism management structure is needed that will facilitate cross-border coordination, while respecting the sovereignty of all partners involved. The importance of cross-border tourism and cultural co-operation is more pragmatic and obvious importance for the mutual strengthening the tourism industries of neighboring countries a research conducted by [18] emphasized that Cross-border tourism requires further research in Asia and elsewhere to contribute the existing research gap on this phenomena.

\subsection{Contemporary Tourism Industry in Nepal}

Tourism is at present one of the most prosperous business in the world, many countries taking precious advantage from their tourism industry. While taking the Nepal account this presence relatively low. according to the [1] exclusive report Nepal place in overall Asia pacific is quiet low in term of direct contribution to GDP China took 1st place in Asia pacific contributing $\$ 263$ billion by 2014 while Nepal contribution recorded $\$ 0.9$ billion.report also shows the direct contribution to employment in Asia Pacific 
China again took first position by generating 23.160 million job, following by India, Thailand, Vietnam, Cambodia, Bangladesh, Myanmar and Nepal (23.024, 2.2102, 2.0, $1.9,0.985,0.9035$ and 0.4874 ) million respectively by 2014 . Report also shows the investment on travel and tourism capital investment in Asia pacific again leading by China invested 4136.8 billion following by India, Thailand, Vietnam, Sri Lanka, Bangladesh, Nepal and Myanmar $(\$ 34.5,7.2,4.6,0.9,0.8,0.4,0.3,0.2,0.1)$ billion dollar respectively. in term of travel and tourism's direct contribution to GDP in Asia pacific Cambodia share 13.5 percent and following by Thailand, Laos, Sri Lanka, Vietnam, Nepal, China, India, Myanmar and Bangladesh (8.6, 5, 4.8, 4.6, 4.3, 2.6, 2.2, 2.2, and 1.9)\% respectively by 2014.all these fact figure clearly indicated that Nepal's aggregate performance is not satisfactory lying under the average. Having abundant resources of Natural and cultural Touristic product Government fails to manage the opportunities. It seems Nepal government need more focus on promoting Nepal destination market and need to put investment forward in tourism infrastructures, scientific destination management, provide fame of securities among foreign and domestic tourists. Nepal need to co-operate with international tourism forum and neighboring countries (China, India...) to cash the it's natural tourism endowment .

\subsection{Glimpse of International Tourist's Arrival in Nepal}

In-term of global international tourists receive Europe accounts 584 million (51\%), Asia pacific 263 million (23\%), America 182 million (16\%), Africa 56 million (5\%) and Middle East 50 million (4\%) by 2014, with a $4.4 \%$ increase on international Tourism [19]. While took a glimpse on Nepal progress, Nepal Received accounted 797,616 in 2013 and 790,118 in 2014 while recorded means by transportation 594,848 by air, 202,768 by land route in 2013, by air and land route recorded 585981 and 204,132 tourists received respectively in 2014 the average stay of tourist in Nepal by 2013 is 12 . 6 days and 2014 recorded 12.44 days. Meanwhile the top arrivals by countries 2013 ranked India, China, USA, Thailand and UK in 2013. In 2014 the rank of major 5 nationalities recorded serially India, China, USA, Sri Lanka, and UK (please see Figure 1 and Figure 2) [20].

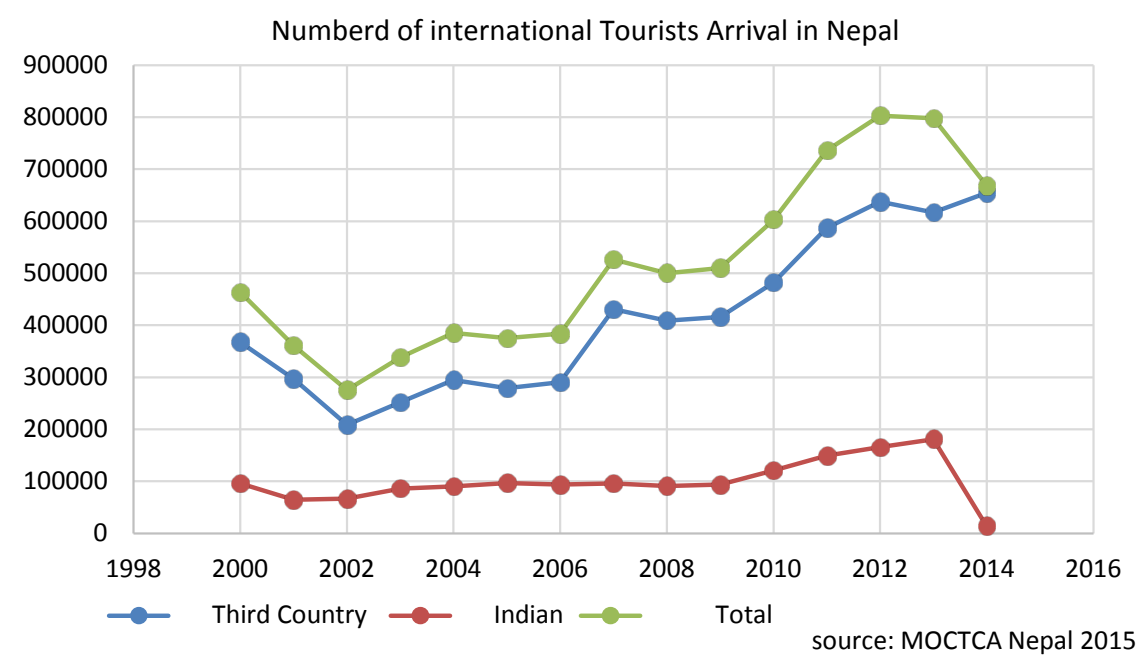

Figure 1. Chinese tourist arrival trend in Nepal. 


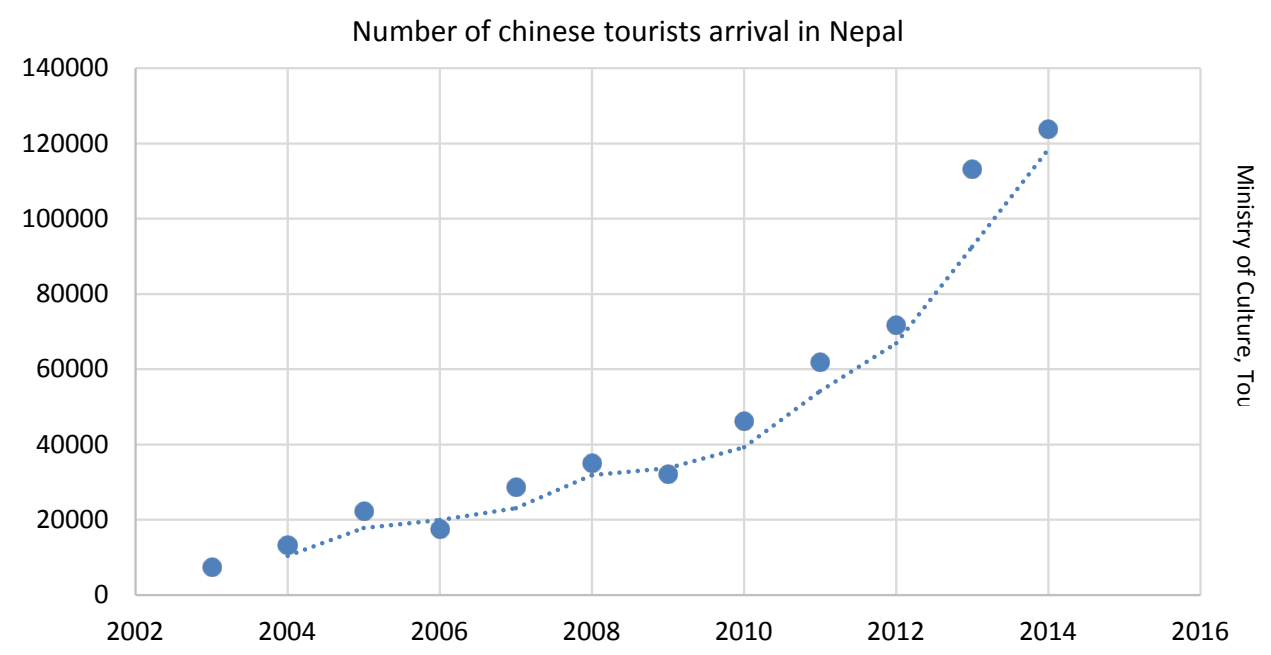

Figure 2. Number of Chinese tourists arrival in Nepal.

From the above source data by Ministry of culture, tourism and civic aviation shows that the trend of Chinese Tourists travelling in Nepalese tourist's destination steadily increment. As being world largest source market the number of Chinese tourists in Nepal is negligible (please see the Figure 2). According to the China National Tourism administration statistics 2015 first nine months (Jan-Sep) Nepalese Citizen arrivals in China recorded 36,600 persons, for different purpose meeting \& business, sightseeing \& leisure, visiting relatives \& friends, worker \& crew and other purpose $(6400,10,900$, 3000,4400 and 14,600) respectively ${ }^{14}$ the trend of Nepalese travelling foreign countries for touristic purpose almost null, however the data recorded by CNTA shows the positive sign for further mutual bilateral co-operation in tourism sectors in near future.

\subsection{Nepal-TAR (China) Tourism Co-Operation Core Issues}

Excluding India's Foreign direct investment in follows in Nepal the Trend of Chinese FDI and Aid granted by China in Nepal increasing dramatically. Since Nepal China established diplomatic relationship august 1995 afterwards China putting her aid and development project in Nepal in-order to co-operate Nepal developing goal. Number of highway, hospital, industries, cultural institutions, science \& technological aid and many more co-operations are enhanced by China. In term of trade and transit in spite of high-altitudinal geographic disadvantages in China and Nepal Trade and transit also positively risen. According to the China's government census the total export and import with Nepal in 2012 ( $\$ 1.96816$ billion, $\$ 29.52$ million), here by 2013 is ( $\$ 2.294146$ billion, $\$ 43.25$ million) respectively. ${ }^{15}$ Reports also show that in term of number of project running by Chinese investors in Nepal listed number one position by surpassing Indian investors (http://www.globaltimes.cn/content/853919.shtml). It is more obvious that after the recent (on March 20-27/2016) official states visit paid by Nepalese Prime minister to China developed looks forward more opportunities foundation. Nepal and China agreed to feasibility study of free trade agreement (FTA), the historic MOU of Nepal's accessibility to Chinese port for outside trade and transit, and understanding of

${ }^{14}$ http://en.cnta.gov.cn/Statistics/TourismStatistics/201511/t20151104_750748.shtml.

${ }^{15}$ http://www.stats.gov.cn/tjsj/ndsj/2014/zk/html/Z1106E.htm. 
enlarge Lhasa-Sigaxe (sigatse) railway to Nepal border port Gyrong (Kerong) by 2020 as well further extension to capital Kathmandu in future ${ }^{16}$. The contemporary sharpen political and high level governments' relationship smoothing the Nepal-China multivariate bilateral ties on its positive direction. As Nepal has officially become a Shanghai Cooperation Organization (SCO) dialogue partner after a memorandum was signed march 2016, also will provide a platform for strengthen and development of trade, tourism and investment in Nepal. Nepal is the largest trade partner with China's TAR. Its $58.6 \%$ trade remain with Nepal

(http://news.xinhuanet.com/english/2016-03/21/c 135209956.htm) beside those spectacular phenomenon relying China-Nepal co-operation, Nepal-TAR frontier not only for two countries also can be a vibrant bridge for south Asian countries easier connectivity's, egg Nepal India, Bangladesh and Bhutan. Mentioning former Nepalese Prime Minister Mr K.P. Sharma Oli's meeting with Chinese president Xi Jin Ping on March. President Xi willing to co-operate with Nepal also purposed "China-Nepal-India trilateral co-operation" and develop the economic corridor along the belt for mutual winwin cooperation. (http://news.xinhuanet.com/english/2016-03/21/c 135209956.htm) if president Xi's and infrastructure development along the region. Idea been articulate and accepted by all parties, for sure it will create a tremendous opportunity on trade and tourism.

While talking about the benefits of border trading places: New economic geographies across Himalayan borderlands Trading places: New economic geographies across $\mathrm{Hi}$ malayan borderlands [21]. Co-operation, we also need to consider the geographic hindrance across the trance Himalayans range as well some remain political issue in TAR. The mobility and accessibility along frontier still not so convenient, since, 2002 people classified as "border inhabitants" only those who live within $30 \mathrm{~km}$ of border both sides have been issued border citizen cards which allow them to across the border without any passport or visa and can travel up to $30 \mathrm{~km}$ on the other side [22]. Coding the remaining Tibet separatist issue of China it's not so easy for Chinese government let freely tourism activates in the border area. Back to few year ago anti-China riot took place in Nepal by Tibetan refugees in spite of Nepal Government extremely support for one China policy [23]. There are some other issues like, weak and fragile roadways connectivity, not sufficient airport in Nepal, Not enough direct flight, insufficient tourist infrastructures along border side, political sensitiveness over TAR, financial incapability Nepalese side, insufficient communication with both side local government level, lack of experience's in cross border co-operative issues, inconvenience of language exchange at all, some of those issue [16] also noticed his research along US-Canada border tourism co-operation. Those composition of Natural and manmade obstacle gap the cross-border co-operation between the countries.

\section{Purposing Marketing Model for Tourism Development in Nepal}

To increase the current marketing competiveness towards targeting Chinese tourists market share through mutual cooperation, Nepal need frame out and redefine certain existing marketing technique.

${ }^{16}$ http://news.xinhuanet.com/english/China/2016-03/23/c_135216927.htm. 


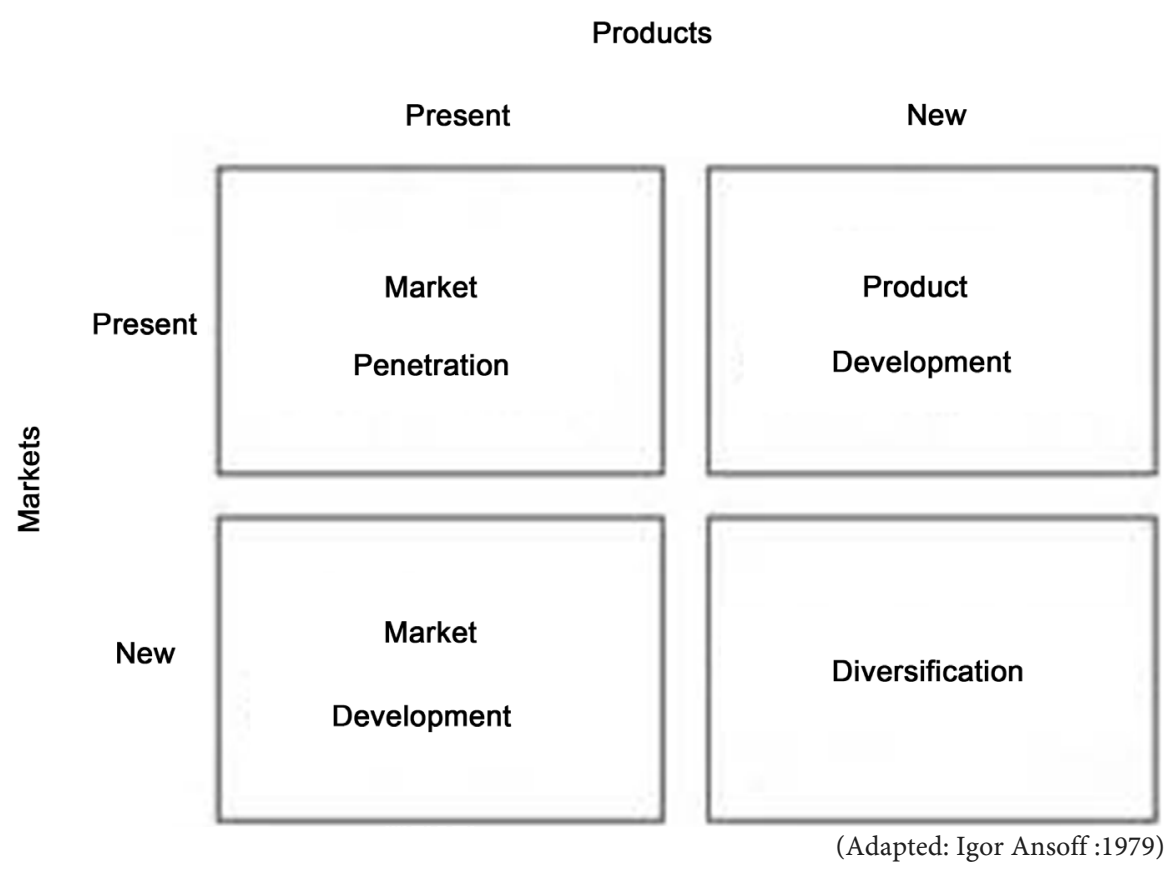

Figure 3. Ansoff matrix ${ }^{17}$.

Co-operative marketing as an instrument may increase strengths, decrease weaknesses, increase the bargaining power of countries against tour operators, and open new windows of opportunity for increased cooperation. At the micro level, corporate strategists claim that cooperation creates "synergy", which means situations where two or more activities or processes complement each other to the extent that their combined effect is greater than the sum of the parts [24]. The Ansoff (1988) product-market expansion grid can be used as a theoretical base to apply co-operative marketing strategies to cross-border tourism marketing growth strategies. The Ansoff grid involves market penetration, market development, product development and diversification. It is a useful tool to identify market opportunities [24]. There is not absolute destination marketing technique in practice, destination marketing is a collective efforts that requires various organization and business in a geographically limited area to harmoniously work together to achieve a common goal [25]. There are many major and subjective issues for significantly increments of Chinese Tourists in to Nepalese tourist destination, to achieve tourism marketing growth strategy Nepalese tourism authority and private tourist industry need to pay, bird of view on Chinese tourists generating region promotion activities. Promotion refers to the communicative activity of marketing. It fills the perceptual and informational gaps that exist between suppliers of tourism (industry) and the tourists (market). Promotion involves the creation and dissimulation of information that the tourist need to take a purchase and consumption decision [25]. According to the [26] the multitude of political, social and economic variables that have influenced the growth of Mainland Chinese outbound tourism so far and no doubt will continue to do so. Since initiate diplomatic ties with PRC, two neighbor never have a hostile relationship, China continuously helping Nepal for its development and stability, that constraints may more benevolent to co-operate on border tourism.

${ }^{17}$ https://en.wikipedia.org/wiki/Ansoff_Matrix, Figure 3. 


\section{Marketing Strategy for Nepal Attract Chinese Outbound Tourists}

Existing tourism product

1. Market penetration

- Minimizing immigration formalities.

- Offer especial price

- Improve border highway.

- Assurance securities issues.

- Revitalize quake affected heritage, monuments, and trekking route.

- Co-operation in promotional campaign.

- Improve ICT.

- Improvement on Accommodation, Transportation, Food, Relaxation, recreation Attitudes of local resident's

Overall service quality Shopping, Scenic spots/areas Tour guides' service.

- Actively participate Chinese travel mart (CITM, GITF, ITE,

WTFS, UTE, BITE, COTTOM etc.)

- Operate regional international airport and direct economy

flight to different cities in China.

- Calling for international tourism conference

- Improve and widen Kathmandu-kodari, Araniko Highway

- Maintain bilateral diplomatic and political adequate relation with PRC.

- Encourage volunteer tourists.

- Strengthening information available to tourists

and tour operators on service quality would also make a difference.

2. Market Development

- To establish media interaction, seminar and workshop in additional cites.

- Increments on sales mission Chinese major and medium size cities.

- Establish information center in various Chinese cities.

- Encourage and invite famous Chinese star, high level leader, celebrities.

- Establish PR companies in tourists generating region.

- Promotional advertise campaign in Chinese mainstream TV, Newspaper, Travel magazine,

- To establish sister city ties with various Chinese cities.

- Co-operation with Chinese giant travel agencies, whole-sellers,

and retailer entire potential tourist generating regions.

- Find the possibilities of co-operation with interested

different countries diplomatic mission in China.

- make a ties and acknowledge among giant Chinese business enterprises.

- Operate direct roadways transportation from Lhasa-Kathmandu.

- Operate NRA economy flight from Lhasa-KTM air route.

- Advertisement campaign along Hong Kong,

Taiwan, Korea, Japan, Macau, Thailand, Singapore's tourist's destination.

- Permitting Chinese agencies franchise in Nepal.

- Negotiation with Chinese banking online system,

alipay, c-trip, elong, mango and Tuniu etc.
New tourism product

3. Tourism Products Development

- Gratis visa fee for Chinese tourists.

- Organize government tourism institution \& travel

agent's incentives interaction program.

- Give incentive for loyal tourists.

- To build new Hotel, restaurants, shopping mall, Disneyland, parks and zoo.

- Give concessions on mountain climb royalties.

- Loosen for business registration for Chinese investors.

- Increase educational and personnel exchange.

- Operate other border land route from existing

- Explorative Nepal's western region based tourist

destination package.

- New cultural-ethnical homestay.

- New adventurous outdoor game.

- Various festival based product

- Encourage personal selling.

- Establish more economic port between frontiers.

- Introduced feminist tour package targeting Chinese female visitors.

4. Tourism Product diversification

- Introduce new adventurous tourist product.

- Make new trail made tour package.

- Make high standard tourist package for wealthy tourists.

- To create New multinational tourist circuit

(Nepal-Sikkim, Bhutan and Tibet)

- Take especial Buddhist Pilgrim package (especial Lumbini)

- Especial care package for senior tourists.

- Create honeymoon and marriage adventurous

Mt. Everest packages.

- Chinese tourist friendly mobile app and game develop.

- Green /eco friendly package.

- Develop common tour package along TAR and Nepal.

- Develop cultural musical, academic research,

filming mass cinemas, charitable package.

- Trans Himalayans exploring. package

- Encourage international chain restaurants, musical- brand etc.

- Integrate package of multi diversify Nepalese touristic product portfolios.

- Developed niche market products.

- Emphasize feminists tourist products.

\section{Conclusion and Recommendations}

Considering cross border tourism and cultural co-operation between Nepal and China as a new vow (strategy) on targeting more than 20 million domestic Chinese tourists traveling neighboring TAR region, it accounts for nearly 100 thousand in Nepal. This study articulates that there are abundant opportunities for both countries in term of cooperation and materializing the resources. Cross-border tourism not only is effective for business, but also increases the knowledge and makes the companies for globaliza- 
tion idea and innovation easier [27]. After the devastated 2015 earthquake Nepal's tourism industries are badly affected, so we have to revitalize Nepalese tourism industry together, which needs more construction than normal. With naturally blessed infinite natural seniors, cultural diversification, suitable climate, wildlife diversification, fountain philosophy, rich art, etc., we can define that Nepal is the blessed destination for tourists around the world. After the century ongoing political insurgency, finally Nepal promulgated her democratic constitution (Sep 20 2015); it shows the end of political intercourse and opens up development era in Nepal. As a historically intimate friend of TAR (China), Nepal needs to look north for development and cooperation issues, while China already articulated more west policies to hold up her development string to western region. Furthermore to establish $21^{\text {st }}$ centaury belt and road initiative master strategy, it is a more scientific work on tourism and cultural co-operation before moving on a longer time-consumed cooperation for both sides. For the temptation of Chinese tourists travelling abroad within group, Nepalese tourism professionals need to more negotiate and cooperate with big travel agencies [28]. Marketing destination campaign travel professionals from Nepal need to more focus on major Chinese outbound source provinces such as Guangdong, Yunnan, Guangxi, Heilongjiang, Fujian, Inner Mongolia, Shanghai, Beijing and Zhejiang respectively [26]. The trend of Chinese outbound travelers shows increment on ADS countries in their golden travel weeks (Spring Festival, National Holidays, Dragon Boot Festival), needing to be understood by Nepalese tourism professionals and government authority for their business plans. The bund understanding is required among center level as well as local level government to enhance successful cooperation on cross-border tourism [29]. Western cluster of majority Chinese terrain hinterland and residents is impoverished, so it may need exceptional policy to integrate those areas in tourism development [30]. The Chinese domestic tourists travelling to TAR are more preferred the land route (Rail, Bus, Private car) compared with airways [31]; $t$ this phenomenon needs to be understood by tourist authorities along TAR and Nepal to get mass tourism from mainland China. While collaboration can create better opportunities for both countries to protect and market unique natural, historical, cultural resources, it may also encourage political stability in the region that will benefit tourism immensely. Nepal-TAR (China) cooperation in tourism marketing strategies has the potential not only to increase efficacy and effectiveness in trade and tourism but also to lead both countries region to develop a more stable and secure environment for tourists. The mutual co-operation initiative may create a way of progress (development) along south-Asian countries. We also highly emphasize to sketch out the new inter trans-regional tourism circuit along India's Sikkim, Nepal Lumbini, Bhutan's Paro and Chin's Tibetan Plateau as a highly reunited Buddhist circuit. We are optimistic that the "One Belt One Road" initiative will be a new driving force of international tourism.

\section{Acknowledgements}

I would like to acknowledge to the CAS-TWAS for supporting and granting me $\mathrm{PhD}$ programs fellowship at the School of Public Affairs, University of Science and Technology, Hefei, China. In addition I would like to acknowledge Nepal tourism board of- 
ficials for providing valuable data during conducting this paper.

\section{References}

[1] World Travel \& Tourism Council (2015) Travel \& Tourism: Economic Impact 2015 Nepal. http://sp.wttc.org/-/media/files/reports/economic-impact-research/countries-2015/nepal20 15.pdf

[2] Manhas, P.S., Kour, P. and Bhagata, A. (2014) Silk Route in the Light of Circuit Tourism: An Avenue of Tourism Internationalization. Procedia-Social and Behavioral Sciences, 144, 143-150. https://doi.org/10.1016/j.sbspro.2014.07.283

[3] Manandhar, G.R. (2009) Prospects and Problems in Promoting Tourism in South Asia: A Regional Perspective. South Asia Economic Journal, 10, 187-207. https://doi.org/10.1177/139156140901000108

[4] Manzurul Mannan Independent, C. (2016) The Silk Road and Shining South Asia: Chinese Expansion in Muslim Bangladesh and Impending Revolution. Silk Roads, Muslim Passages. The Islam Question in China's Expansion, Singapore, 29-30 July 2015.

[5] Lama, J.Y. (2013) China and Its Peripheries: Securing Nepal in South Asia. The Institute of Peace and Conflict Studies (IPCS).

[6] Stevens, S. (1977) Tourism and Development in Nepal. KAS Paper 8, 523-538.

[7] Sharma, B.C. (2033) Nepalko Yetihasik Roop Rekha. Krishna Kumaridevi, Banaras.

[8] Shrestha, H.P. (2012) Tourism in Nepal: A Historical Perspective and Present Trend of Development Paryant. Himalayan Journal of Sociology \& Antropology, 5, 54-75.

[9] Bernstein, J. (1970) The Wildest Dreams of Kew: A Profile of Nepal. Simon and Schuster, Newyork, USA.

[10] Parajuli, B.K. (2011) Impact of "Nepal Tourism Year 2011" on Tourist Arrival in Pokhara. Himalayan Journal of Sociology \& Antropology, 6, 22-51.

[11] Guo, R. (2011) China's Regional Development and Tibet. Springer Science+Business Media Singapore, Singapore.

[12] Su, M.M. and Wall, G. (2009) The Qinghai-Tibet Railway and Tibetan Tourism: Travelers' Perspectives. Tourism Management, 30, 650-657. https://doi.org/10.1016/j.tourman.2008.02.024

[13] Timothy, D.J. and Tosun, C. (2003) Tourists' Perceptions of the Canada-USA Border as a Barrier to Tourism at the International Peace Garden. Tourism Management, 24, 411-421. https://doi.org/10.1016/S0261-5177(02)00113-9

[14] Sessa, D.A. (1973) International Co-Operation in Tourism. The Tourist Review, 28, 19-21 https://doi.org/10.1108/eb057677

[15] Selin, S. and Chavez, D. (1995) Developing an Evolutionary Tourism Partnership Model. Annals of Tourism Research, 22, 844-856. https://doi.org/10.1016/0160-7383(95)00017-X

[16] Timothy, D.J. (1999) Cross-Border Partnership in Tourism Resource Management: International Parks along the US-Canada Border. Journal of Sustainable Tourism, 7, 182-205. https://doi.org/10.1080/09669589908667336

[17] Vodeb, K. (2010) Cross-Border Regions as Potential Tourist Destinations along the Slovene Croatian Frontier. Tourism and Hospitality Management, 16, 219-228.

[18] Hampton, M.P. (2010) Enclaves and Ethnic Ties: The Local Impacts of Singaporean Cross-Border Tourism in Malaysia and Indonesia. Singapore Journal of Tropical Geography, 31, 239-253. https://doi.org/10.1111/j.1467-9493.2010.00393.x

[19] UNWTO (2014) UNWTO Annual Report 2014.

[20] Ministry of Culture, Tourism \& Civil Aviation (2015) Nepal Tourism Statistics 2014. 
[21] Harris, T. (2013) Trading Places: New Economic Geographies across Himalayan Borderlands. Political Geography, 35, 60-68. https://doi.org/10.1016/j.polgeo.2012.12.002

[22] Shneiderman, S.B. (2013) Himalayan Border Citizens: Sovereignty and Mobility in the Nepal-Tibetan Autonomous Region (TAR) of China Border Zone. Political Geography, 35, 25-36. https://doi.org/10.1016/j.polgeo.2013.04.001

[23] Aryal, S.R. (2009) Tibetans Protest in Capital.

[24] Tosun, C., Timothy, D.J., Parpairis, A. and Macdonald, D. (2005) Cross-Border Cooperation in Tourism Marketing Growth Strategies. Journal of Travel \& Tourism Marketing, 18, 5-23. https://doi.org/10.1300/J073v18n01 02

[25] Benjamin, B. (2010) Promoting an Emerging Tourism Destination. Global Journal of Management and Business Research, 10, 21-28.

[26] Guo, Y., Kim, S.S. and Timothy, D.J. (2007) Development Characteristics and Implications of Mainland Chinese Outbound Tourism. Asia Pacific Journal of Tourism Research, 12, 313-332. https://doi.org/10.1080/10941660701760995

[27] Cankar, S.S., Seljak, J. and Petkovšek, V. (2014) Factors That Influence Cross-Border Cooperation between Businesses in the Alps-Adriatic Region. Economic Research-Ekonomska Istraživanja, 27, 304-319. https://doi.org/10.1080/1331677X.2014.952091

[28] World Tourism Cities Federation (2014) Market Research Report on Chinese Outbound Tourist (City) Consumption. 1-51. http://www.ipsos.com.cn/sites/default/files/11.2014EN tourism.pdf

[29] Bufon, M. and Markelj, V. (2010) Regional Policies and Cross-Border Cooperation: New Challenges and New Development Models in Central Europe. Revista Română de Geografie Politică XII, No. 1, 18-28.

[30] Fallis, A., Mohamad, A.A., Lo, M.-C., Songan, P., Wee, A.Y., Rasul, G. and Palmowski, T. (2010) Study on Sustainable Development of China's Tourism. Tourism, Management, 1, 187-207.

[31] EU SME Centre (2014) Tourism Market in China.

\section{Submit or recommend next manuscript to SCIRP and we will provide best service for you:}

Accepting pre-submission inquiries through Email, Facebook, LinkedIn, Twitter, etc.

A wide selection of journals (inclusive of 9 subjects, more than 200 journals)

Providing 24-hour high-quality service

User-friendly online submission system

Fair and swift peer-review system

Efficient typesetting and proofreading procedure

Display of the result of downloads and visits, as well as the number of cited articles

Maximum dissemination of your research work

Submit your manuscript at: http://papersubmission.scirp.org/

Or contact ojbm@scirp.org 